\title{
Preferential adherence of cable-piliated Burkholderia cepacia to respiratory epithelia of CF knockout mice and human cystic fibrosis lung explants
}

\author{
UMADEVI SAJJAN, YIJUN WU*, GERALDINE KENT ${ }^{\dagger}$ and JANET FORSTNER \\ Research Institute, Departments of Structural Biology and Biochemistry, * Developmental Biology and \\ †Animal Laboratory Services, Hospital for Sick Children, Toronto, Ontario, Canada
}

\begin{abstract}
The Burkholderia cepacia complex consists of at least five well-documented bacterial genomovars, each of which has been isolated from the sputum of different patients with cystic fibrosis (CF). Although the world-wide prevalence of this opportunist pathogen in CF patients is low (1-3\%), 'epidemic' clusters occur in geographically isolated regions. Prevalence in some of these clusters is as high as 30-40\%. The majority of CF $B$. cepacia isolates belong to genomovar III, but the relationship between genomovar and virulence has not yet been defined. Because the initial stage of infection involves bacterial binding to host tissues, the present study investigated differences in the binding of representative isolates of all five genomovars to fixed nasal sections of UNC cftr (-/-) and $(+/+)$ mice and to human lung explants, biopsy and autopsy tissue of CF and nonCF patients. Binding was highest for isolates of genomovar III, subgroup RAPD type 2, but only if the isolates expressed the cable pili phenotype. Antibodies to the 22-kDa adhesin of cable pili virtually abolished binding. Binding occurred only to cftr (-/-) nasal sections or to CF lung sections and was negligible in cftr $(+/+)$ or human non-CF, histologically normal lung sections. Unlike normal epithelia, the hyperplastic epithelia of CF bronchioles were enriched in cytokeratin 13, a 55-kDa protein that has previously been shown to act as a receptor in vitro for cable-piliated $B$. cepacia. These findings may help to explain the high transmissibility of Cbl-positive, genomovar III strains of $B$. cepacia among CF patients.
\end{abstract}

\section{Introduction}

Burkholderia cepacia was described originally as a phytopathogen [1], but has been recognised since the 1970 s as an opportunist respiratory pathogen in cystic fibrosis (CF) patients [2-5]. It is also seen in some patients with immunosuppression and chronic granulomatous disease $[6,7]$. In CF patients infection with $B$. cepacia tends to occur in 'epidemic' geographic clusters, with regional differences in prevalence. In Canada as a whole, the prevalence is $8-10 \%$ [8], but in the Toronto adult $\mathrm{CF}$ clinic prevalence is much higher (46\%) [9]. Patients who become colonised show unpredictable and variable clinical responses, ranging from no apparent deleterious consequences to a rapidly fatal necrotising pneumonia and septicaemia (the

Received 9 Jan. 2000; accepted 2 March 2000. Corresponding author: Dr J. Forstner (email: jfforst@ sickkids.on.ca). cepacia syndrome). The same variability of outcome has been noted in other centres, suggesting that only some CF patients are susceptible to serious respiratory disease with this pathogen. However, large national surveys indicate that patients infected with $B$. cepacia exhibit an overall adverse clinical course, with higher mortality rates than those colonised only with Pseudomonas aeruginosa, the more common opportunist pathogen in CF [4, 10-13]. In particular, B. cepaciainfected $\mathrm{CF}$ patients have a much higher post-operative mortality rate $(64 \%$ versus $19 \%)$ in the first 3 months following double lung transplantation [14]. Because the organism is generally resistant to antibiotics and other forms of therapy, there is a pressing need to discover more about the mechanisms of its pathogenesis, including the colonisation process, virulence properties and mechanisms of drug resistance.

B. cepacia isolates from sputum of CF patients and from environmental sources (plants, soil) are geneti- 
cally diverse and have been categorised into at least five genomic groups (genomovars), based on computerassisted cluster analyses of whole-cell protein profiles, fatty acid content and DNA-DNA and DNA-rRNA hybridisation assays [15]. The major 'epidemic' clusters affecting Canadian CF patients are associated with genomovar III. Less frequently, genomovars II ( $B$. multivorans) and IV have been found. The rapid spread of genomovar III from patient to patient attests to its high index of transmissibility. Environmental strains tend to belong to genomovar I and are rarely cultured from $\mathrm{CF}$ patients.

The relationship between genomovar and virulence has not yet been defined. Potential virulence determinants of $B$. cepacia include a potent haemolysin [16], a siderophore [17], LPS [18, 19], an extracellular protease [20], lipases [21], a melanin-like pigment [22] and surface cable pili. The latter have been shown to mediate bacterial adherence to mucin and epithelial cells $[23,24]$. It is not known which (if any) of these factors has the most negative impact on CF patients. However, because acquisition of $B$. cepacia tends to increase with age and duration of lung disease, virulence probably also depends in large measure on compromised host defences. The chronic stasis of mucus in the airways, impaired mucociliary clearance, altered electrolyte composition, defective CFTR, inactive defensins, epithelial metaplasia, neutrophil products and other consequences of pre-existing infection and inflammation, may all play a role in $B$. cepacia persistence and host susceptibility to further lung damage.

One highly transmissible clone (also known as the ET strain) is prevalent in Canadian and UK CF centres, belongs to genomovar III, RAPD type 2, and carries the 'epidemic' DNA marker (BCESM) [25]. This strain also carries the cblA gene encoding the major cable pilin subunit [26, 27]. In previous studies involving a group of $15 \mathrm{CF}$ isolates from Ontario, all the isolates were ET strains and 14 of them expressed the unique cable pili phenotype [26, 28]. The pili were found to mediate specific binding to mucin carbohydrates as well as to a $55-\mathrm{kDa}$ protein present in buccal epithelial cells $[23,24,29]$. Recently, the $55-\mathrm{kDa}$ cell receptor has been identifed as cytokeratin 13 [30]. The actual adherence mechanism involves a 22-kDa adhesin protein associated with the cable pili $[23,24]$.

The present study involves a test of B. cepacia adherence to fixed tissue sections of $\mathrm{CF}$ and control respiratory epithelia; nasal epithelia of UNC CF knockout mice [31] and human lung explant, biopsy or autopsy tissues were used. Despite the lack of overt lung pathology in UNC cftr knockout (-/-) mice, their nasal epithelia exhibit mild inflammatory lesions and chloride flux pathology that closely mimic human $\mathrm{CF}$ respiratory epithelia $[32,33]$. The binding properties of representative isolates of $B$. cepacia from all five genomovars to the mouse and human tissue sections were compared, to decide whether specific genomovar strains might be considered to have a greater potential for adherence and colonisation in vivo than others. The sections were also used to ascertain if $\mathrm{CF}$ tissue was more susceptible than non-CF tissue to $B$. cepacia binding.

\section{Materials and methods}

\section{B. cepacia strains and culture conditions}

Sputum isolates BC5, BC7, BC24 and BC45 were from the $B$. cepacia collection held in this laboratory and have been described previously [24, 26, 28]. Isolate $\mathrm{BC} 7$, which was used extensively in the present study, was isolated originally from a 15-year-old CF patient who was clinically healthy until acquisition of $B$. cepacia. The patient died with the cepacia syndrome 1 month later. Isolate BC45 was cultured from a CF patient who was chronically infected with $P$. aeruginosa for 20 years, then acquired B. cepacia, but did not die until 4 years later at the age of 43 . This patient never developed the cepacia syndrome. Isolate BC24 was isolated from a patient who had severe lung disease (and harboured P. aeruginosa) for several years before acquiring $B$. cepacia at the age of 21 . He died 2 years later but without signs of the cepacia syndrome. Isolate BC5 was isolated from a 16-year-old patient with only mild symptoms of lung disease. Three years later the patient was alive, but moved out of town and was lost to follow-up. All other isolates in Table 1 were from the B. cepacia research panel of strains held by Dr E. Mahenthiralingan (Department of Pediatrics, University of British Columbia). Isolate J2315, donated by Dr J. Govan (Edinburgh), was cultured during the 1980s from a CF patient who is still alive. Species identity of all isolates was reconfirmed in this laboratory by growth on $B$. cepacia selective isolation agar [34]. Isolates were stored at $-80^{\circ} \mathrm{C}$ and routinely subcultured on Brain Heart Infusion Agar (Becton Dickinson, Cockeysville, MD, USA) at $37^{\circ} \mathrm{C}$ for $48 \mathrm{~h}$ before use. Single colonies were inoculated into $10 \mathrm{ml}$ of Tryptic Soy Broth (TSB; Difco) and grown at $37^{\circ} \mathrm{C}$ for $24 \mathrm{~h}$ on an orbital shaker at $150 \mathrm{rpm}$ in preparation for experiments.

\section{Fluorescein isothiocyanate (FITC)-labelling of B. cepacia}

All B. cepacia isolates were labelled with FITC following the method of Falk et al. [35]. Labelled bacteria were recovered by centrifugation, washed three times with phosphate buffered saline (PBS) containing bovine serum albumen (BSA) $0.1 \%$ and resuspended in PBS containing BSA $1 \%$ to give $10^{8} \mathrm{cfu} / \mathrm{ml}$. Samples were examined by light and fluorescence microscopy (Leica Dialux 22, Willowdale, Ont, Canada) to confirm that all bacteria from each isolate were fluorescent. 
Either $100-$ or $200-\mu 1$ volumes of the bacterial suspension were used in binding experiments.

\section{Nasal epithelial sections of mice}

Animal experiments were performed under protocols approved by the animal ethics committee at the Hospital for Sick Children, Toronto. Wild-type C57BL/6J mice (Jackson Laboratory, Bar Harbor, Maine, USA) fed a normal chow diet were used as controls. UNC cftr $(-/-)$ and cftr $(+/+)$ mice [31] from the same colony were housed in clean conventional rooms free of rodent viral, mycoplasma and bacterial pathogens and maintained on a liquid diet as described earlier [33]. Mice were killed between 6 and 8 weeks of age by intraperitoneal chloral hydrate $(3.6 \%)$ and exsanguination. Transverse nasal sections were made $2.8 \mathrm{~mm}$ from the tip of the nose, nasal specimens were fixed in buffered formalin $10 \%$, decalcified in formic acid 8\% [36] and embedded in paraffin. Nasal sections ( $5 \mu$ thick) were cut for haematoxylin and eosin ( $\mathrm{H}$ and $\mathrm{E}$ ) staining or bacterial binding assays.

In some experiments, $4 \mu \mathrm{l}$ of a $1 \%$ solution of the amphipathic detergent polyoxyethylene-9-lauryl ether (Polidocanol; Sigma) were instilled into the right nostril of wild-type C57B6/6J mice to induce a mild inflammatory reaction [37]. After $30 \mathrm{~min}$ mice were killed and nasal sections were prepared as described above. Binding of bacterial isolates was compared in the normal and inflamed nasal cavities by fluorescence microscopy.

\section{Lung sections from $C F$ and non-CF patients}

Formalin-fixed, paraffin-embedded lung explants, biopsy or autopsy tissue were obtained from the pathology tissue library at the Hospital for Sick Children, Toronto. For each patient sample one or more sections were available from proximal regions (to show many large bronchioles and parenchyma) and peripheral regions (containing mainly small bronchioles and alveoli). Sections included explants of six CF patients, a biopsy section from one non-CF patient and autopsy lung sections from two non-CF patients. The lung sections of the non-CF patients showed no microscopic pathology and were used as normal controls.

\section{Bacterial binding to tissue sections}

Human lung or mouse nasal sections were deparaffinised in xylene, rehydrated in graded alcohol, washed twice in PBS and blocked with BSA 3\% for at least $2 \mathrm{~h}$ at room temperature. FITC-labelled B. cepacia $(0.1$ or $0.2 \mathrm{ml}$ of $10^{8} \mathrm{cfu} / \mathrm{ml}$ ) in PBS-BSA $1 \%$ were then added and incubated for $1 \mathrm{~h}$ at $37^{\circ} \mathrm{C}$ in a humidified chamber. The slides were washed six times with PBS-BSA 0.1\% to remove non-adherent bacteria, fixed in buffered formalin $10 \%$ for $15 \mathrm{~min}$, washed three times with PBS, counter-stained with Mayers' haematoxylin and mounted. Sections were examined in a fluorescence microscope and bacterial binding was quantified by counting the number of bacteria associated with mouse nasal tissue (10 fields per section) or human respiratory epithelia, as detailed in the Results section. Binding of $\leqslant 10$ bacteria was considered to be non-specific background binding.

\section{Antibody to the 22-kDa adhesin of cable pili}

Immunoreactivity of isolates with a polyclonal antibody to the $22-\mathrm{kDa}$ adhesin of cable pili was tested by immunoblots of outer-membrane protein preparations, by protocols described previously [24]. This antibody has been shown to react with a doublet band centred at $22 \mathrm{kDa}$ in isolates expressing surface cable pili. To test for the involvement of cable pili in the binding of $B$. cepacia to lung sections, FITC-labelled isolate BC7 was pre-incubated with the antibody to the $22-\mathrm{kDa}$ adhesin for $1 \mathrm{~h}$ at $37^{\circ} \mathrm{C}$, centrifuged, resuspended in PBS-BSA $1 \%$ and incubated with lung sections as in a standard binding assay.

\section{Detection of the cblA gene and BCESM DNA marker in isolates}

PCR amplification was used to detect the $c b l A$ gene by an approach similar to that described by Joshi et al. [38]. Briefly, intact bacterial cells $\left(1 \times 10^{6} \mathrm{cfu}\right)$ of each isolate were used as a source of template DNA. The reaction mixture was heated at $95^{\circ} \mathrm{C}$ for $12 \mathrm{~min}$ to release DNA from the bacteria and then subjected to 30 cycles of amplification $\left(1 \mathrm{~min}\right.$ at $94^{\circ} \mathrm{C}, 1 \mathrm{~min}$ at $60^{\circ} \mathrm{C}$, $1 \mathrm{~min}$ at $72^{\circ} \mathrm{C}$ ). A typical reaction mixture consisted of the $c b l A$ gene specific primers GTCCAGAAGGACAT TACCGTC (sense primer), GGGCTTAGCTACCC GAAGCCGGGCT (antisense primer) $(0.4 \mu \mathrm{M}$ each), dNTPS $\left(200 \mu \mathrm{M}\right.$ each), B. cepacia $\left(1 \times 10^{6} \mathrm{cfu}\right)$, Amplitaq Gold DNA polymerase (2.0 U, Perkin-Elmer Cetus, Norwalk, CT, USA), $\mathrm{MgCl}_{2}(1.5 \mathrm{mM})$ and Tris$\mathrm{HCl}$ buffer $(10 \mathrm{mM}$ containing $50 \mathrm{mM} \mathrm{KCl})$. Amplicons were analysed by electrophoresis on agarose $1.5 \%$ gel and stained with ethidium bromide to detect the expected 447-bp cblA gene product [26]. The presence of the BCESM DNA marker in isolates was confirmed by PCR by using methods described earlier by Mahenthiralingam et al. [39].

\section{Buccal epithelial cell fractions}

Buccal epithelial cells (BEC) were fractionated to produce a cytokeratin-rich fraction by the method of Franke et al. [40]. This fraction contains the major cytokeratin $(55 \mathrm{kDa})$ that acts as a receptor for Cblpiliated strains of B. cepacia in binding assays [30], and was used in the present study either as a receptor in bacterial overlay assays or as an inhibitor of bacterial binding to tissue sections. Binding of $B$. 
cepacia isolates to blots of BEC extracts was tested by overlay of ${ }^{35} \mathrm{~S}$-labelled bacteria as described earlier [23, 30]. For inhibition studies, isolates were pre-incubated with the BEC extract for $1 \mathrm{~h}$ at $37^{\circ} \mathrm{C}$, centrifuged, resuspended in PBS-BSA $1 \%$ and incubated with lung sections as in a standard binding assay.

\section{Immunodetection of cytokeratin 13 in $C F$ and non-CF lung sections}

Cytokeratin 13 was detected by indirect immunofluorescence with a monoclonal antibody (MAb) to cytokeratin 13 (Novocastra Laboratories) (1:100 v:v) according to the manufacturer's instructions. Detection was by an anti-mouse IgG-Cy3 fluorophore (1:250 v:v). Sections were counterstained by Meyer's haematoxylin.

\section{Results}

\section{Nasal histology of wild-type, cftr (-/-) and} (+/+) mice

$\mathrm{H}$ and $\mathrm{E}$ nasal sections taken from wild-type (chow-fed C57BL/6J) and UNC cftr (+/+) mice (six per group) exhibited normal morphology of olfactory, stratified squamous, septal and turbinate epithelia. In particular, the respiratory epithelia of the septa and turbinates showed a normal distribution of pseudostratified ciliated columnar cells, goblet cells and basal cells [41]. However, in each of nine cftr (-/-) mice examined there was evidence of mild inflammation with mucosal swelling, luminal exudates, epithelial hyperplasia, patchy losses of cilia and sparse leucocyte infiltration in the lamina propria (not shown). These pathological changes were very similar to those described earlier for UNC cftr $(-/-)$ mice [32]. In two wild-type mice given intranasal Polidocanol detergent $30 \mathrm{~min}$ before killing, there was evidence of mild mucosal swelling and partial denudation of surface respiratory epithelia on the treated side of the nostril.

\section{Binding of FITC-labelled B. cepacia to nasal epithelia}

Each isolate shown in Table 1 was labelled with FITC and separately overlaid in triplicate on fixed nasal sections prepared from four wild-type, one cftr $(+/+)$ and five $c f t r(-/-)$ mice. Because $c f t r(+/+)$ mice were in short supply, and preliminary experiments revealed no differences in binding between wild-type and $c f t r(+/+)$ sections, wild-type nasal sections were used in most cases instead of cftr $(+/+)$ sections. None of the isolates bound to $c f t r(+/+)$ or wild-type nasal sections, but binding of a subset of the genomovar III, RAPD type 2 isolates (BC5, BC7, BC24, C5424) was prominent on the epithelium and luminal exudates of cftr $(-/-)$ sections, as shown for one of the isolates in Fig. 1. Table 2 shows representative results for isolate BC7 after counting the number of bacteria bound to the epithelium in 10 randomised fields $(0.4 \times 0.4 \mathrm{~mm})$ per section. Isolates $\mathrm{BC} 5, \mathrm{BC} 24$ and $\mathrm{C} 5424$ gave similar results. Isolates $\mathrm{BC} 45$ and $\mathrm{J} 2315$, which also belong to genomovar III, RAPD type 2, did not bind and were indistinguishable from the environmental isolate ATCC 25416 ( $<10$ bacteria per field) and all other isolates.

As the mildly inflamed respiratory epithelia of $c f t r$ $(-/-)$ mice appeared to be much more receptive to bacterial binding than wild-type or $c f t r(+/+)$ nasal epithelium, an attempt was made to mimic these conditions by inducing a mild inflammation in the nares of wild-type mice by brief pre-treatment with detergent. However, as shown in Table 2, binding by isolate $\mathrm{BC} 7$ was not enhanced, indicating that an acute inflammatory reaction was insufficient to render the tissues suitable for bacterial binding. Presumably the more chronic inflammatory condition found in $\mathrm{cftr}$

Table 1. Identity and sources of B. cepacia isolates

\begin{tabular}{|c|c|c|c|c|c|c|c|}
\hline Isolate no. & $\begin{array}{l}\text { Geographic } \\
\text { location }\end{array}$ & Source & Genomovar & RAPD & BCESM & cblA gene & $\begin{array}{l}\text { 22-kDa } \\
\text { adhesin }\end{array}$ \\
\hline ATCC 25416 & ATCC & Onion & I & 039 & - & - & - \\
\hline CEP 509 & Australia & $\mathrm{CF}$ & I & 041 & - & - & - \\
\hline C5393 & Toronto & $\mathrm{CF}$ & II & 003-BM & - & - & - \\
\hline JTC & Vancouver & CGD & II & BM-X & - & - & - \\
\hline BC5 & Toronto & $\mathrm{CF}$ & III & 002 & + & + & + \\
\hline BC7 & Toronto & $\mathrm{CF}$ & III & 002 & + & + & + \\
\hline $\mathrm{BC} 24$ & Toronto & $\mathrm{CF}$ & III & 002 & + & + & + \\
\hline $\mathrm{BC} 45$ & Toronto & $\mathrm{CF}$ & III & 002 & + & + & - \\
\hline C5424 & Vancouver & $\mathrm{CF}$ & III & 002 & + & + & + \\
\hline $\mathrm{J} 2315$ & UK & $\mathrm{CF}$ & III & 002 & + & + & - \\
\hline $\mathrm{C} 4455$ & Toronto & $\mathrm{CF}$ & III & 006 & + & - & - \\
\hline C1394 & UK & $\mathrm{CF}$ & III & 013 & + & - & - \\
\hline PC184 & $\mathrm{OH}, \mathrm{USA}$ & $\mathrm{CF}$ & III & 017 & + & - & - \\
\hline LMG14291 & Belgium & $\mathrm{CF}$ & IV & gIV-X & - & - & - \\
\hline PC254 & WA, USA & $\mathrm{CF}$ & V & 008 & - & - & - \\
\hline
\end{tabular}

Genomovar status of all isolates was determined by Vandamme et al. [15]. RAPD typing was done by Mahenthiralingam et al. [39]. The BCESM and cblA gene were detected by PCR as described in Materials and methods. The 22-kDa adhesin was detected by Western blot analysis of outer-membrane preparations with the anti-adhesin antibody. 

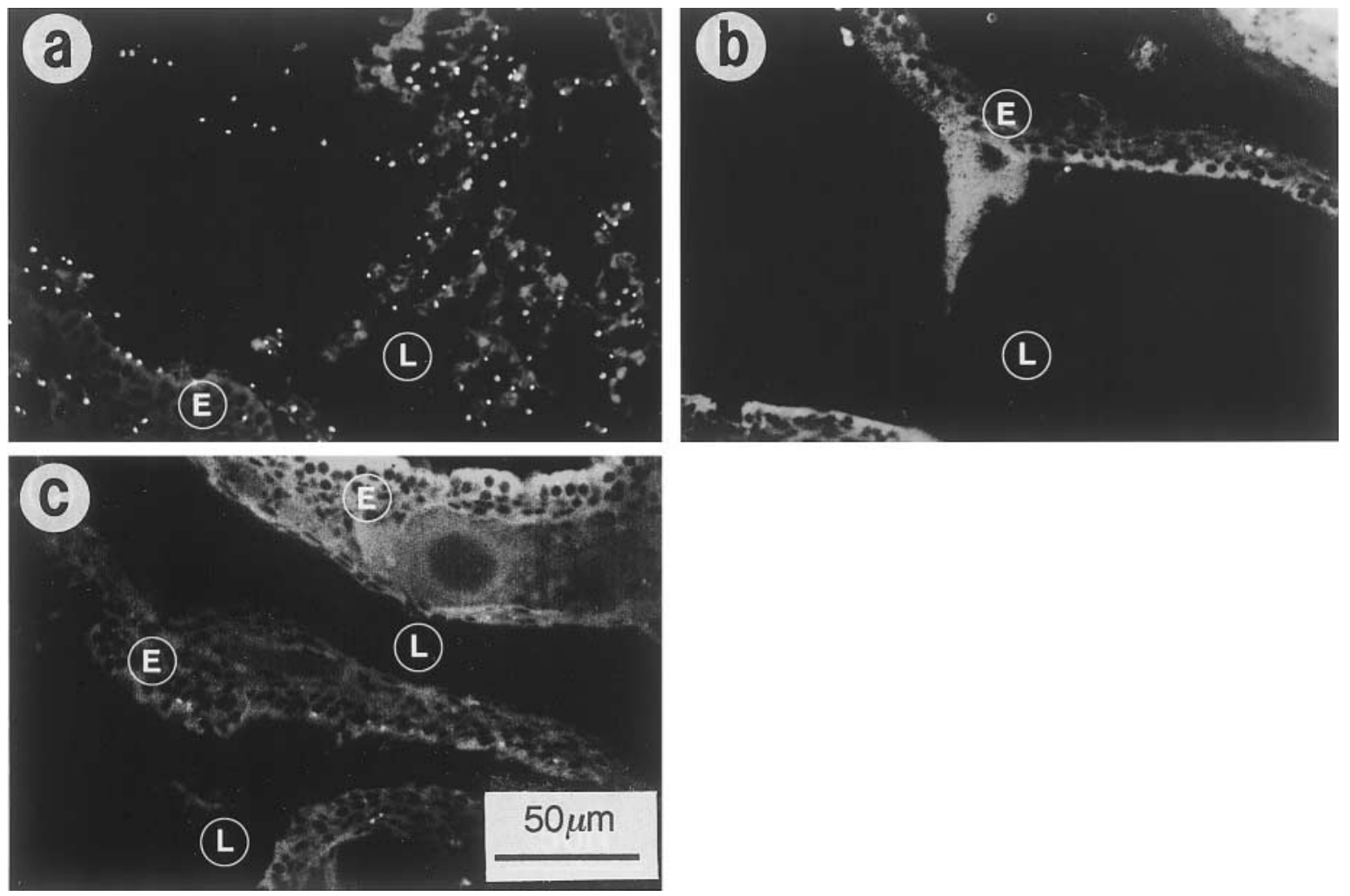

Fig. 1. Binding of isolates BC7 and ATCC 25416 to nasal sections of $c f t r(-/-)$ and wild-type mice. Nasal sections from cftr $(-/-)$ and wild-type mice were incubated with FITC-labelled isolate BC7 or ATCC $25416(0.1 \mathrm{ml}$ of $1 \times 10^{8} \mathrm{cfu} / \mathrm{ml}$ ) for $1 \mathrm{~h}$ at $37^{\circ} \mathrm{C}$. Sections were washed to remove unbound bacteria, fixed in buffered formalin $10 \%$ and counter-stained with haematoxylin. Airway epithelia and lumens are represented by 'E' and 'L' respectively. (a) and (b) isolate $\mathrm{BC} 7$ binding to $\mathrm{cftr}(-/-)$ and wild-type mouse nasal sections respectively; (c) ATCC 25416 binding to cftr $(-/-)$ mouse nasal section.

Table 2. B. cepacia (isolate $\mathrm{BC7}$ ) binding to mouse nasal sections

\begin{tabular}{lc}
\hline Mouse type & $\begin{array}{c}\text { Mean (SEM) number of } \\
\text { bacteria bound }\end{array}$ \\
\hline cftr (+/+) & $2.6(2.0)$ \\
Wild-type & $2.7(2.0)$ \\
Wild-type & $4.0(2.4)$ \\
Wild-type & $3.7(1.7)$ \\
Wild-type & $1.7(1.4)$ \\
$c f t r(-/-)$ & $95.9(12.8)$ \\
$c f t r(-/-)$ & $75.3(8.9)$ \\
$c f t r(-/-)$ & $82.2(3.5)$ \\
$c f t r(-/-)$ & $43.0(7.1)$ \\
$c f t r(-/-)$ & $22.1(2.5)$ \\
Wild-type (detergent) & $2.6(2.0)$ \\
Wild-type (detergent) & $2.1(1.5)$ \\
\hline
\end{tabular}

FITC-labelled isolate $\mathrm{BC} 7$ was incubated in triplicate with fixed sections of wild-type, UNC cftr (+/+), or cftr (-/-) mice or wildtype mice pre-treated with detergent $30 \mathrm{~min}$ before killing. After washing to remove non-bound bacteria, bound bacteria were counted in 10 fields and the mean and SEM were calculated for each mouse section; $<10$ adherent bacteria per field was considered background, non-specific binding.

$(-/-)$ tissues was required to make them conducive to binding by $\mathrm{BC} 7$.

\section{Histology of human lung sections}

Experiments similar to those described for nasal sections were undertaken with human CF lung explants and non-CF biopsy or autopsy tissue. There were six CF patients (aged 14-35) of whom the first four (Table 3) were colonised by both $B$. cepacia and $P$. aeruginosa. Patients 5 and 6 were colonised only by $P$. aeruginosa. Lung sections obtained from three nonCF individuals (not shown) were histologically normal and were used for comparison.

The CF lung sections (two-to-five per patient) included proximal and distal regions, and contained large and small bronchioles, as well as alveoli. Most bronchiolar airways were enlarged, filled with mucopurulent exudates and lined by hyperplastic epithelia, or epithelia undergoing squamous metaplasia. There was partial loss of cilia, patchy exfoliation of cell layers and dense peribronchiolar infiltrations of inflammatory cells. Terminal and respiratory bronchioles, which are normally devoid of goblet cells in healthy lungs, contained numerous goblet cells. In alveolar regions, emphysema, thickened interstitium with mild fibrosis and inflammatory cells in the air spaces were observed. The pathological changes resembled those described earlier by Baltimore et al. [42] for CF patients infected by $P$. aeruginosa. Occasionally regions of more normal looking thin-walled alveoli (designated 'thin' in Table 3) were also recognised. Morphological differences could not be distinguished between patients infected with $P$. aeruginosa alone versus $P$. aeruginosa plus $B$. cepacia. 
Table 3. Bound bacteria in CF lung explants

\begin{tabular}{|c|c|c|c|c|c|}
\hline \multirow{3}{*}{$\begin{array}{l}\text { Patient } \\
\text { no. }\end{array}$} & \multicolumn{5}{|c|}{ Mean (SEM) number of bacteria bound to } \\
\hline & \multicolumn{2}{|c|}{ Bronchiolar epithelium } & \multirow{2}{*}{$\begin{array}{c}\text { Luminal } \\
\text { exudates } \\
\text { (large } \\
\text { bronchioles) }\end{array}$} & \multicolumn{2}{|c|}{ Alveolar septa } \\
\hline & large & small & & thick & thin \\
\hline 1 & $61.5 \pm 6.1$ & $21.3 \pm 2.3$ & $136 \pm 12.5$ & $39.7 \pm 4.1$ & $12.5 \pm 1.8$ \\
\hline 2 & $76.2 \pm 5.5$ & $14.5 \pm$ & $144 \pm 11.7$ & $54.2 \pm 4.4$ & $14.7 \pm 1.8$ \\
\hline 3 & $61.3 \pm 6.9$ & $19.4 \pm 2.7$ & $166 \pm 7.9$ & $45.0 \pm 6.2$ & $15.9 \pm 7.0$ \\
\hline 4 & $56.6 \pm 7.9$ & $25.2 \pm 1.8$ & $158 \pm 12.0$ & $51.0 \pm 4.2$ & $16.5 \pm 1.6$ \\
\hline 5 & $65.6 \pm 6.6$ & $12.5 \pm 2.1$ & $146 \pm 8.1$ & $55.0 \pm 4.7$ & $18.7 \pm 2.0$ \\
\hline 6 & $59.4 \pm 7.9$ & $18.8 \pm 3.1$ & $113 \pm 11.6$ & $37.0 \pm 4.7$ & $13.5 \pm 2.4$ \\
\hline $\begin{array}{l}\text { Mean (SEM) of } \\
\text { six patients }\end{array}$ & $63.4 \pm 5.6$ & $18.6 \pm 1.2$ & $144 \pm 16.2$ & $47.0 \pm 6.2$ & $15.3 \pm 2.1$ \\
\hline
\end{tabular}

FITC-labelled isolate BC7 was incubated with fixed sections of CF lung explants. Non-bound bacteria were removed by washing, and the number of bound bacteria was counted per $100-\mu \mathrm{m}$ length of epithelium or $100 \mu \mathrm{m}^{2}$ of exudate in 6-18 (average 10) fields. Values represent mean and SEM. Thick versus thin alveolar septa refer to hyperplastic, swollen versus normal septa, respectively. Large bronchioles include small bronchi and regular bronchioles, small bronchioles refer to terminal and respiratory bronchioles. All six patients were colonised by $P$. aeruginosa, and patients 1-4 were also colonised by B. cepacia at the time of double lung transplant.

\section{Binding of B. cepacia isolates to human lung} sections

Binding of B. cepacia isolates (listed in Table 1) to CF and non-CF lung sections was quantified by counting the number of bacteria bound per $100-\mu \mathrm{m}$ lengths of epithelium or per $100 \mu \mathrm{m}^{2}$ of luminal exudate in an average of 10 fields per section. As observed with the mice nasal sections, only isolates $\mathrm{BC} 5, \mathrm{BC} 7, \mathrm{BC} 24$ and C5424 exhibited significant binding ( $>10$ bacteria per field), and they bound only to $\mathrm{CF}$ lung sections. Representative results for isolate $\mathrm{BC} 7$ in $\mathrm{CF}$ and non$\mathrm{CF}$ bronchioles are shown in Fig. 2. Quantification of
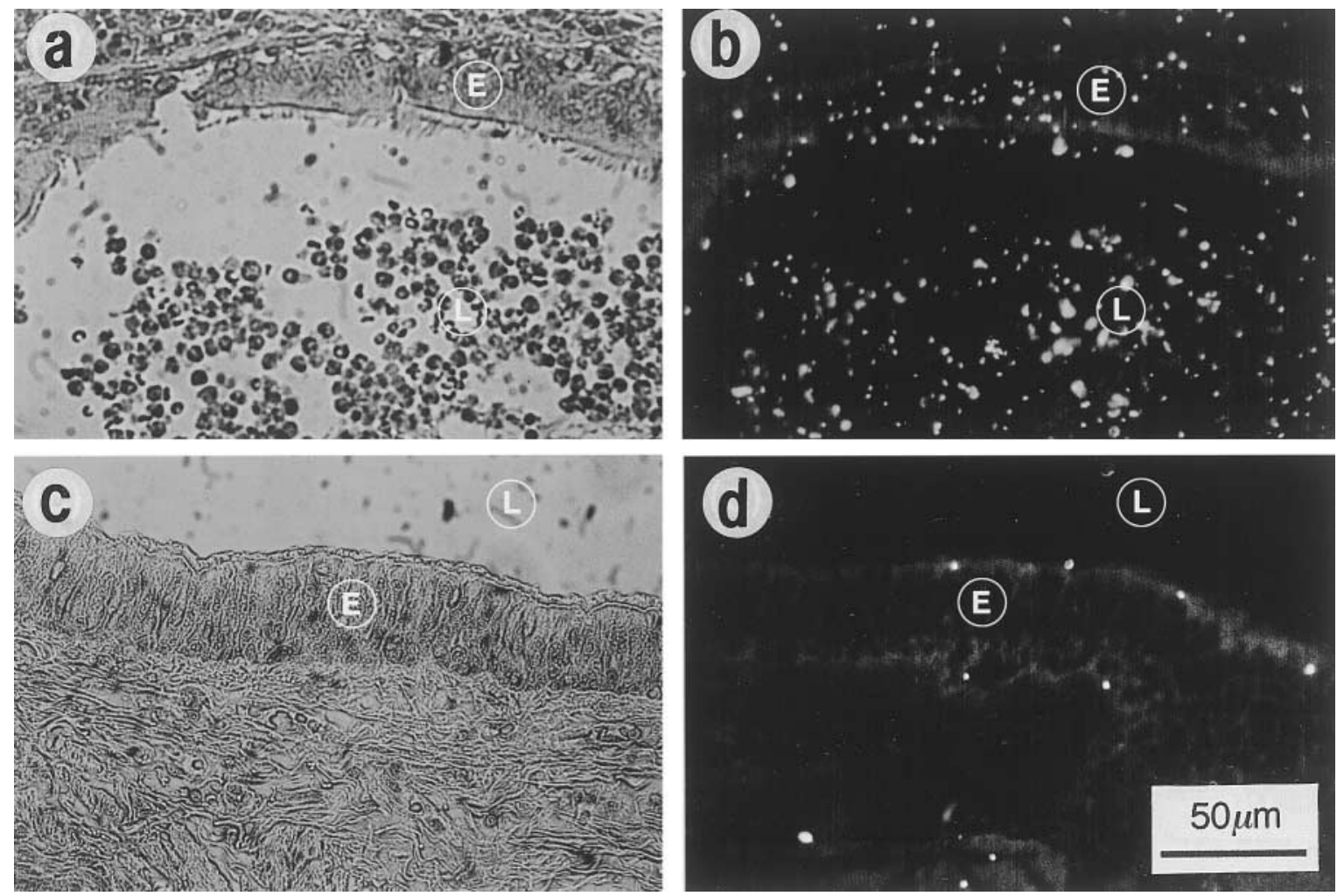

Fig. 2. Binding of isolate $\mathrm{BC} 7$ to $\mathrm{CF}$ and non-CF bronchioles. Sections of $\mathrm{CF}$ and non-CF lungs were incubated with FITC-labelled isolate $\mathrm{BC} 7\left(0.2 \mathrm{ml}\right.$ of $\left.1 \times 10^{8} \mathrm{cfu} / \mathrm{ml}\right)$ for $1 \mathrm{~h}$ at $37^{\circ} \mathrm{C}$. Sections were washed, fixed in buffered formalin $10 \%$ and counter-stained with haematoxylin. Airway epithelia and lumens are represented by ' $\mathrm{E}$ ' and ' $\mathrm{L}$ ' respectively. (a) and (c) haematoxylin-stained sections of CF and non-CF bronchioles respectively; (b) and (d) isolate BC7 binding to sections corresponding to (a) and (c). 
binding to different CF lung structures of each patient is presented in Table 3. The isolates that exhibited binding bound strongly to hyperplastic, damaged CF bronchiolar epithelia (especially in the larger bronchioles), to purulent exudates in the lumen and to thickened alveolar septa. There was no binding to vascular endothelia or interstitia. No differences were observed in the binding of $B$. cepacia to tissues obtained from patients infected with $P$. aeruginosa versus $P$. aeruginosa plus $B$. cepacia.

\section{Role of the 22-kDa adhesin}

Immunoblots of each isolate with the polyclonal antibody to the $22-\mathrm{kDa}$ adhesin revealed that the four isolates shown earlier to be capable of binding to $\mathrm{CF}$ tissues contained the adhesin (Table 1 and Fig. 3), although trace amounts were also detected in isolates BC45 and J2315 (Fig. 3). The presence of the cblA gene for the $\mathrm{Cbl}$ pili subunit was not confined to the four high binding isolates. The other two members of the genomovar III, RAPD type 2 classification (J2315 and $\mathrm{BC} 45$ ), which did not bind to $\mathrm{CF}$ tissues, also carry the cblA gene (Table 1).

To assess further the role of the adhesin in the binding of $B$. cepacia to lung sections, isolate $\mathrm{BC} 7$ was preincubated with the anti-adhesin antibody (1 in 50 dilution) or with pre-immune serum (no inhibitor control) and binding to three $\mathrm{CF}$ (and one non-CF) lung sections was measured. Fig. 4 shows that the antiadhesin caused a dramatic inhibition of binding of isolate $\mathrm{BC} 7$ to bronchiolar epithelium and luminal exudates of $\mathrm{CF}$ tissue sections. The anti-adhesin antibody had no effect on non-binding isolates. These experiments indicate that not all genomovar III isolates carrying the cblA gene have the $\mathrm{Cbl}$ pili phenotype, but those that do utilise the $22-\mathrm{kDa}$ adhesin to bind to $\mathrm{CF}$ epithelial cells.

\section{Effect of the cytokeratin extract of BEC}

All the isolates shown in Table 1 were metabolically labelled with ${ }^{35} \mathrm{~S}$-methionine and tested individually in bacterial overlay assays for their binding to the $55-\mathrm{kDa}$ protein of cytokeratin extracts of BEC (Fig. 5). Isolates that belonged to genomovar III, RAPD type 2 and were cblA positive and adhesion positive $\left(\mathrm{CblA}^{+} / \mathrm{Adh}^{+}\right)$ included BC5, BC7, BC24 and C5424 (Table 1). These isolates bound to cytokeratin 13. The two isolates (BC45 and J2315) that also belonged to genomovar III, RAPD type 2 , but were $\mathrm{cblA}^{+} / \mathrm{Adh}^{-}$did not bind to

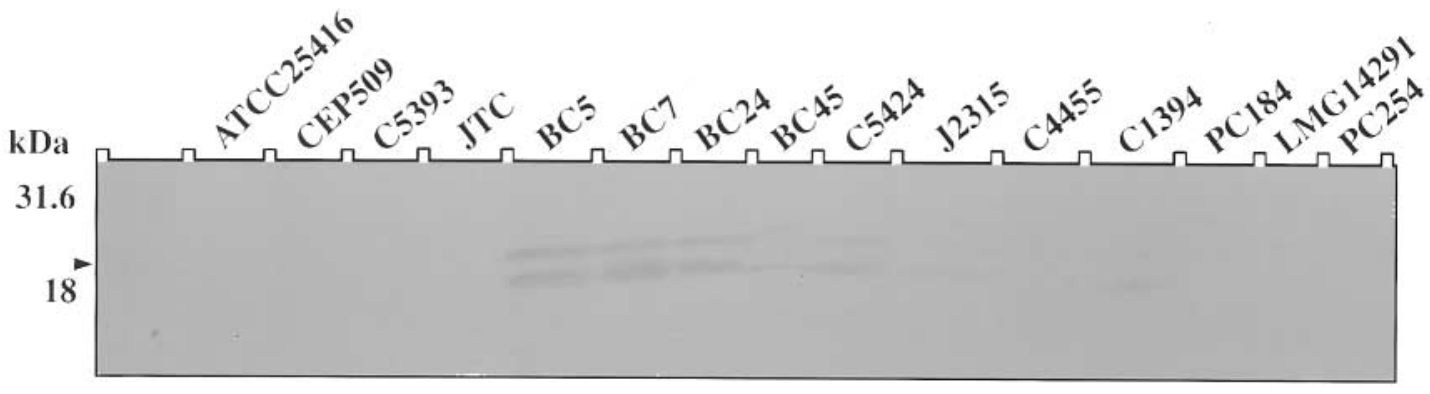

Fig. 3. Detection of the $22-\mathrm{kDa}$ adhesin in B. cepacia isolates. Outer-membrane fractions from each $B$. cepacia isolate were electrophoresed on SDS-polyacrylamide gels $(16 \%)$, transferred to nitrocellulose membranes and blocked with BSA 3\%. Membranes were incubated with the anti-22-kDa adhesin antibody ( 1 in $1000 \mathrm{v} / \mathrm{v}$ ), washed, and the bound antibody was detected by anti-rabbit IgG conjugated to alkaline phosphatase and NBT-BCIP substrate. Molecular mass standards $(\mathrm{kDa})$ are shown on the left. The adhesin is a doublet centred at $22 \mathrm{kDa}$.
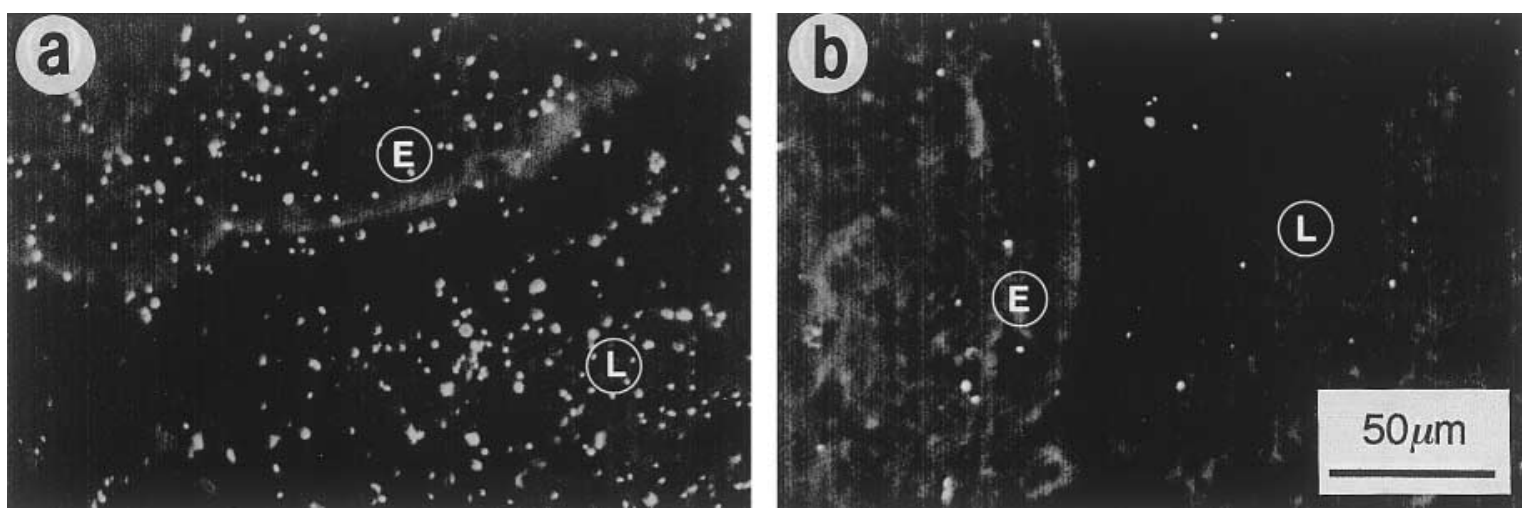

Fig. 4. Inhibition of strain BC7 binding to $\mathrm{CF}$ lung sections by the anti-22-kDa adhesin antibody. FITC-labelled BC7 strain cells were pre-incubated with pre-immune serum or the anti-adhesin antibody ( 1 in 50 dilution), centrifuged, suspended in PBS-BSA $1 \%$ and incubated with CF lung sections. Airway epithelia and lumens are represented by 'E' and 'L' respectively. (a) pre-immune serum (positive control); (b) anti-22-kDa adhesin antibody (inhibitor). 


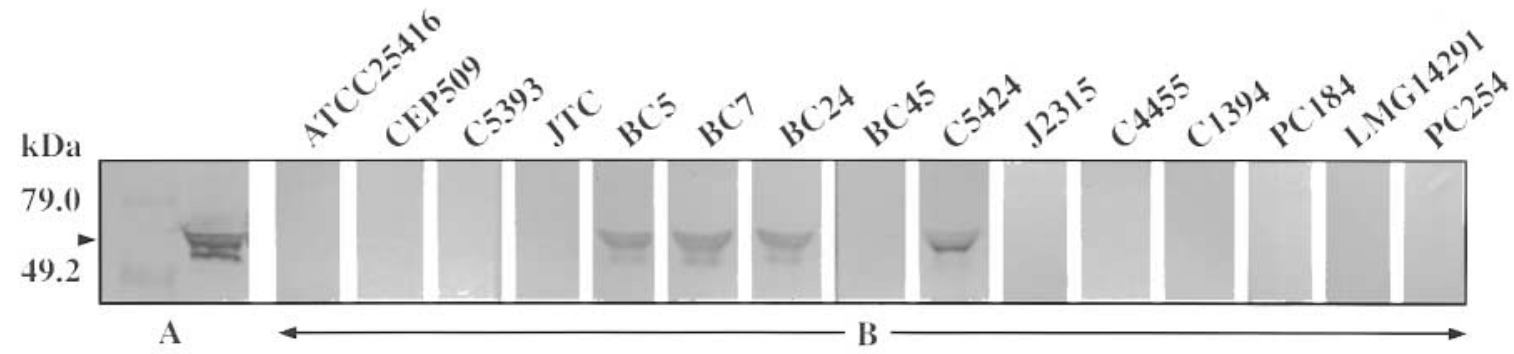

Fig. 5. Binding of B. cepacia isolates to cytokeratin 13. The cytokeratin-rich fraction from $10^{4}$ BEC was subjected to SDS-PAGE $(12 \%$ gel), proteins were transferred to nitrocellulose membranes and blocked with BSA $3 \%$ in PBS. The membranes were incubated with ${ }^{35}$ S-labelled B. cepacia isolates, washed and bound bacteria were detected by autoradiography (B). Molecular mass standards are shown in panel A, left lane. Four isolates bound to a 55-kDa band (B), which was identified in panel A, right lane, as cytokeratin 13 by a MAb specific for cytokeratin 13.

cytokeratin 13 . Thus the $22-\mathrm{kDa}$ adhesin plays a major role in mediating binding. No other genomovar samples bound to the $55-\mathrm{kDa}$ protein or to any other component in the extracts.

Purified CK13 is not available commercially, thus its ability to inhibit binding could not be tested. However, isolate $\mathrm{BC} 7$ was pre-incubated with the cytokeratin-rich fraction of BEC (which contains CK13 and CK4 [43]) and then with $\mathrm{CF}$ lung explant sections. As shown in Fig. 6 the cytokeratin fraction caused a major reduction in binding. Bacteria that had been exposed only to the cytokeratin suspension buffer (control) were not inhibited.

\section{Distribution of cytokeratin 13 in $C F$ and non-CF lung sections}

As only $\mathrm{CF}$ lung tissue exhibited susceptibility to binding by Cbl-positive B. cepacia, the present study tested the possibility that CF airway epithelia, especially regions exhibiting pathological hyperplasia or squamous metaplasia, might show an increased expression of cytokeratin 13. Immunofluorescent detection in $\mathrm{CF}$ and non-CF lungs was performed with a specific $\mathrm{MAb}$ that recognises cytokeratin 13 . In non-CF tissues (normal bronchioles) cytokeratin 13 was not detected, as was expected from the previous distribution studies of Moll et al. [44]. However, in CF airways, cytokeratin 13 was detected in the epithelial lining of almost all small bronchi and bronchioles. $\mathrm{CF}$ bronchioles of relatively normal appearance contained cytokeratin 13 in the region of basal cells, whereas bronchioles exhibiting more hyperplasia and squamous metaplasia gave a fluorescent signal throughout the mucosa, i.e., in basal, middle and luminal surface regions (Fig. 7). Unfortunately, the antigen 'unmasking' process (heating tissue sections at $121^{\circ} \mathrm{C}$ for $1 \mathrm{~min}$ ) that is part of the procedure required to detect cytokeratin 13, effectively prevented the attempts to perform colocalisation experiments of bound bacteria and cytokeratin. Nevertheless, the findings indicate that cytokeratin 13 expression is significantly increased in CF airway epithelia, and becomes apically disposed in severely affected mucosae. These are the same areas in which $B$. cepacia binding was found to be most pronounced.

\section{Discussion}

The results of this study indicate that there is a prominent functional difference among B. cepacia
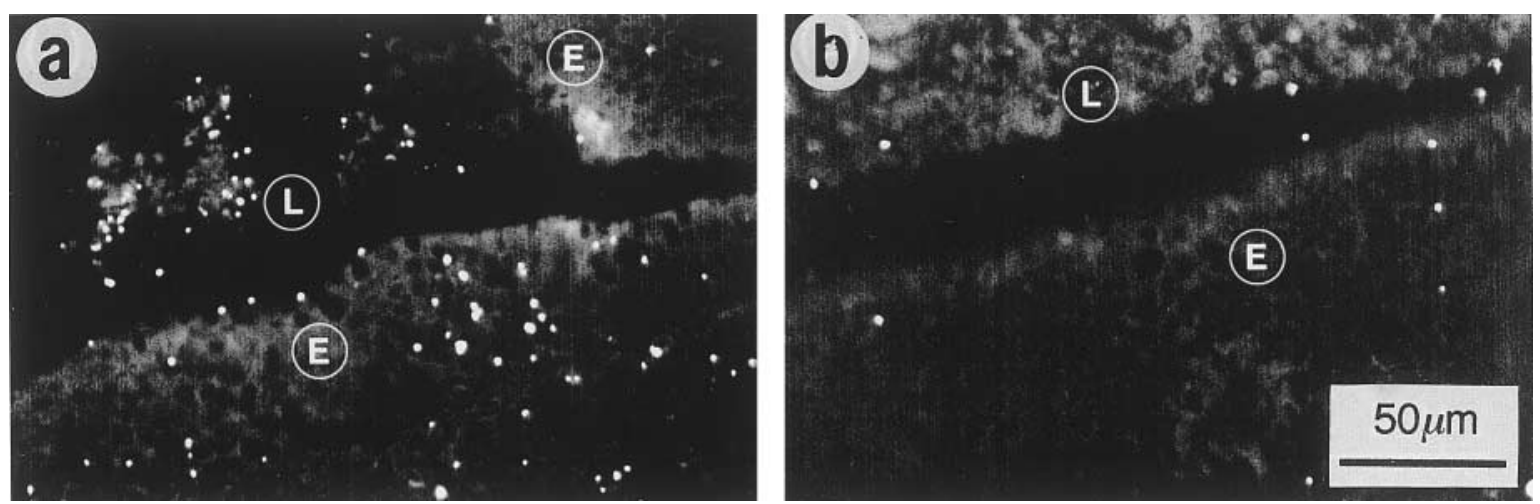

Fig. 6. Inhibition of strain $\mathrm{BC} 7$ binding to $\mathrm{CF}$ lung sections by cytokeratin-rich fractions from BEC. FITC-labelled BC7 strain cells were pre-incubated with the cytokeratin fraction from $10^{6} \mathrm{BEC}$ or cytokeratin suspension buffer (control) for $1 \mathrm{~h}$ at $37^{\circ} \mathrm{C}$, centrifuged, resuspended in $1 \mathrm{ml}$ of PBS and incubated with CF lung sections. Airway epithelia and lumens are represented by 'E' and 'L' respectively. (a) no inhibitor; (b) cytokeratin fraction. 

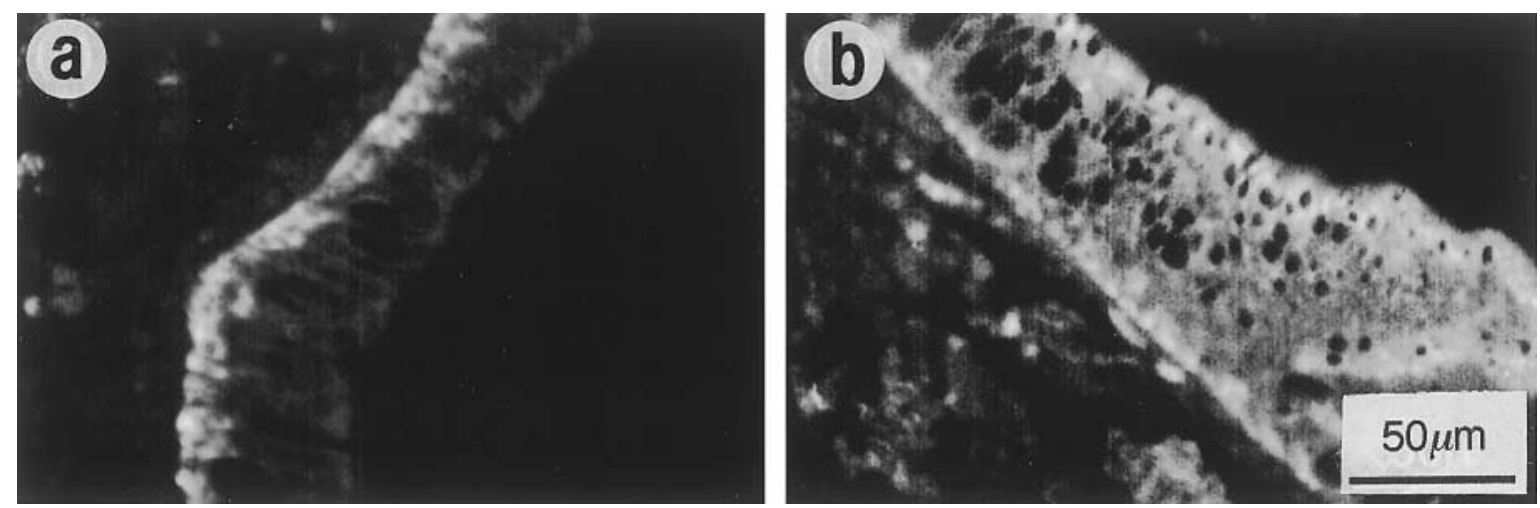

Fig. 7. Immunodetection of cytokeratin 13 in CF lung. Sections from CF lungs were deparaffinised, rehydrated and antigens were 'unmasked' by heating under pressure in sodium citrate buffer for $1 \mathrm{~min}$. Sections were blocked with normal donkey serum for $2 \mathrm{~h}$, incubated with a MAb to cytokeratin $13(1 \mathrm{in} 100 \mathrm{v} / \mathrm{v})$ and bound antibody was detected by anti-mouse donkey IgG conjugated to CY3 fluorophore (1 in $250 \mathrm{v} / \mathrm{v}$ ). (a) CK13 detected in the basal region of CF bronchiolar epithelium; (b) CK13 distributed throughout the hyperplastic CF bronchiolar epithelium, including the apical luminal margin.

genomovars in their ability to bind to CF airway tissue. Genomovar III strains belonging to RAPD type 2 were adherent, but within this group, only those isolates that expressed surface cable pili and the $22-\mathrm{kDa}$ adhesin were able to bind. These findings extend earlier in-vitro studies which showed that cable pili mediate $B$. cepacia attachment to the isolated $55-\mathrm{kDa}$ cytokeratin of BEC [23, 30]. Non-cable-piliated isolates did not bind. The two non-binding isolates (BC45 and J2315) in the RAPD type 2 group did not express the adhesin, even though they carry the cblA gene and are indistinguishable from the others by current DNA typing methods. Presumably a mutation in a regulatory gene or mutation(s) in one or more of the genes required for pilin assembly, transport, anchorage or polymerisation, may be responsible. However, as most of the genomovar III isolates in the research panel (and in our own published collection) do exhibit cable pili [26], the cable pili phenotype appears to be the most common genomovar III phenotype in CF patients.

Some Cbl-negative strains, particularly those belonging to genomovar II, have also been reported to be associated with 'epidemic' spread in CF patients living in other geographic areas $[4,12,15]$. A previous study [45] showed that genomovar III isolates with no or very few cable pili (BC45 and BC61 respectively) were able to bind to galactolipid receptors (particularly asialo GM1 and Gb3). Other genomovars were not tested in those experiments. Asialo GM1 has been reported to be increased in $\mathrm{CF}$ epithelial cells, and may be a candidate receptor for binding by Cbl-negative $B$. cepacia. However, as the present study failed to detect binding to $\mathrm{CF}$ tissues by strains belonging to other genomovars, the biological significance of in-vitro galactolipid binding remains in question. Therefore, the mechanism by which Cbl-negative strains attach to host tissue in vivo remains unsolved.

A second major finding in this study was that human CF tissues (mainly damaged epithelial linings of small airways and thickened alveolar septa) were much more susceptible to Cbl-positive B. cepacia binding than non-CF tissues. Even the $c f t r(-/-)$ mice exhibited a stronger tendency to bind the Cbl-positive strains to their nasal mucosae than $c f t r(+/+)$ or wild-type mice. Apart from the absence of functional CFTR, the only obvious feature that distinguished $c f t r(-/-)$ mice was the presence of an underlying mild nasal inflammation. Attempts to reproduce this state by inducing an acute mild inflammatory reaction in wild-type mice with detergent were insufficient to cause an increase in $B$. cepacia binding. Thus the chronic nature of the inflammatory process in $\mathrm{CF}$, which probably entails continuous subtle damage inflicted by leucocytes or leucocyte products, may be an important prerequisite for Cbl-positive B. cepacia binding.

Normal epithelial tissues engaged in repair after injury undergo a remodelling of the epithelium and shifts in cytokeratin expression, with an increase in cytokeratin 13 [46]. The observed preferential attachment of Cblpositive $B$. cepacia to cytokeratin 13 in vitro, the inhibition of binding of isolate $\mathrm{BC} 7$ to lung tissue by the cytokeratin fraction of $\mathrm{BEC}$, and the increase in fluorescent staining of cytokeratin 13 in damaged $\mathrm{CF}$ airway tissues, all point to the interpretation that cytokeratin 13 plays an important receptor role for cable-piliated B. cepacia interactions in CF lungs.

The present studies do not prove that Cbl-positive $B$. cepacia isolates induce lung damage. However, initial binding of bacteria to host tissues is generally considered to be an important virulence determinant. As the results of the present study show that Cbl-positive isolates $\left(\mathrm{cblA}^{+} / \mathrm{Adh}^{+}\right)$preferentially adhere to chronically damaged $\mathrm{CF}$ epithelia enriched in CK13, these isolates are expected to have a greater potential than other isolates or genomovars to persist, infect and damage the $\mathrm{CF}$ lung. Preliminary experiments in this laboratory, with repeat nasal instillations of isolate $\mathrm{BC} 7$ or ATCC 25416 into cftr (-/-) and $(+/+)$ mice, have 
shown that after 2-3 weeks there is a much greater persistence of $B$, cepacia isolate $\mathrm{BC} 7$ in cftr $(-/-)$ than in $c f t r(+/+)$ lungs (unpublished observations). Further research will now be undertaken to extend these experiments and create an animal model suitable for studies of virulence of B. cepacia.

We thank Dr E. Cutz, Department of Pathology, Hospital for Sick Children, for providing $\mathrm{CF}$ and non-CF lung sections, Dr E. Mahenthiralingam, Department of Pediatrics, UBC, for providing isolates from the B. cepacia research panel and Ms Yanchun Wang, Department of Cell Biology, Hospital for Sick Children, for help in the preparation of mouse nasal sections. Financial support was received from the Canadian Cystic Fibrosis Foundation.

\section{References}

1. Burkholder WH. Sour skin, a bacterial rot of onion bulbs. Phytopathol 1950; 40: 115-117.

2. Govan JRW, Brown PH, Maddison J et al. Evidence for transmission of Pseudomonas cepacia by social contact in cystic fibrosis. Lancet 1993; 342: 15-19.

3. Isles A, Macluskey I, Corey M et al. Pseudomonas cepacia infection in cystic fibrosis: an emerging problem. $J$ Pediatr 1984; 104: 206-210.

4. LiPuma JJ. Burkholderia cepacia. Management issues and new insights. Clin Chest Med 1998; 19: 473-86.

5. Simmonds EJ, Conway SP, Ghoneim ATM, Ross H, Littlewood JM. Pseudomonas cepacia: a new pathogen in patients with cystic fibrosis referred to a large centre in the United Kingdom. Arch Dis Child 1990; 65: 874-877.

6. Lacy DE, Spencer DA, Goldstein A, Weller PH, Darbyshire P. Chronic granulomatous disease presenting in childhood with Pseudomonas cepacia septicaemia. J Infect 1993; 27: 301-304.

7 O'Neil KM, Herman JH, Modlin JF, Moxon ER, Winkelstein JA. Pseudomonas cepacia: an emerging pathogen in chronic granulomatous disease. J Pediatr 1986; 108: 940-942.

8. Speert DP. The Canadian situation vis a vis colonization infection with $B$. cepacia. Program and abstracts of the 3 rd meeting of the international Burkholderia cepacia working group held in British Columbia, Canada. 1997.

9. Johansen HK, Kovesi TA, Koch C, Corey M, Hoiby N, Levison H. Pseudomonas aeruginosa and Burkholderia cepacia infection in cystic fibrosis patients treated in Toronto and Copenhagen. Pediatr Pulmonol 1998; 26: 89-96.

10. Frangolias DD, Mahenthiralingam E, Rae S et al. Burkholderia cepacia in cystic fibrosis. Variable disease course. Am J Respir Crit Care Med 1999; 160: 1572-1577.

11. Rosenfeld M, Davis R, FitzSimmons S, Pepe M, Ramsey B Gender gap in cystic fibrosis mortality. Am J Epidemiol 1997; 145: 794-803.

12. Whiteford ML, Wilkinson JD, McColl JH et al. Outcome of Burkholderia (Pseudomonas) cepacia colonisation in children with cystic fibrosis following a hospital outbreak. Thorax 1995; 50: $1194-1198$

13. Corey M, Edwards L, Levison H, Knowles M. Longitudinal analysis of pulmonary function decline in patients with cystic fibrosis. J Pediatr 1997; 131: 809-814.

14. Chaparro C, Corey M, Forstner J, Sajjan U, Tullis E. B. cepacia infection and lung transplantation in patients with cystic fibrosis: The Toronto Experience. Sixth meeting of the international Burkholderia cepacia working group held in Banff, Alberta. 1999

15. Vandamme P, Holmes B, Vancanneyt M et al. Occurrence of multiple genomovars of Burkholderia cepacia in cystic fibrosis patients and proposal of Burkholderia multivorans sp. Int $J$ Syst Bacteriol 1997; 47: 1188-1200.

16. Hutchison ML, Poxton IR, Govan JRW. Burkholderia cepacia produces a hemolysin that is capable of inducing apoptosis and degranulation of mammalian phagocytes. Infect Immun 1998; 66: 2033-2039

17. Darling P, Chan M, Cox AD, Sokol PA. Siderophore production by cystic fibrosis isolates of Burkholderia cepacia. Infect Immun 1998; 66: 874-877.
18. Hughes JE, Stewart J, Barclay GR, Govan JRW. Priming of neutrophil respiratory burst activity by lipopolysaccharide from Burkholderia cepacia. Infect Immun 1997; 65: 4281-4287.

19. Zughaier SM, Ryley HC, Jackson SK. Lipopolysaccharide (LPS) from Burkholderia cepacia is more active than LPS from Pseudomonas aeruginosa and Stenostrophomonas maltophilia in stimulating tumor necrosis factor alpha from human monocytes. Infect Immun 1999; 67: 1505-1507.

20. McKevitt AI, Bajaksouzian S, Klinger JD, Woods DE. Purification and characterization of an extracellular protease from Pseudomonas cepacia. Infect Immun 1989; 57: 771-778.

21 Lonon MK, Woods DE, Straus DC. Production of lipase by clinical isolates of Pseudomonas cepacia. J Clin Microbiol 1988; 26: 979-984.

22. Zughaier SM, Ryley HC, Jackson SK. A melanin pigment purified from an epidemic strain of Burkholderia cepacia attenuates monocyte respiratory burst activity by scavenging superoxide anion. Infect Immun 1999; 67: 908-913.

23. Sajjan US, Forstner JF. Role of a 22-kilodalton pilin protein in binding of Pseudomonas cepacia to buccal epithelial cells. Infect Immun 1993; 61: 3157-3163.

24. Sajjan US, Forstner JF. Identification of the mucin-binding adhesin of Pseudomonas cepacia isolated from patients with cystic fibrosis. Infect Immun 1992; 60: 1434-1440.

25. Mahenthiralingam E, Campbell ME, Henry DA, Speert DP. Epidemiology of Burkholderia cepacia infection in patients with cystic fibrosis: analysis by randomly amplified polymorphic DNA fingerprinting. $J$ Clin Microbiol 1996; 34: 2914-2920.

26. Sajjan US, Sun L, Goldstein R, Forstner JF. Cable (Cbl) type II pili of cystic fibrosis-associated Burkholderia (Pseudomonas) cepacia: nucleotide sequence of the $c b l \mathrm{~A}$ major subunit pilin gene and novel morphology of the assembled appendage fibers. J Bacteriol 1995; 177: 1030-1038.

27. Sun L, Jiang R-Z, Steinbach S et al. The emergence of a highly transmissible lineage of $c b l+$ Pseudomonas (Burkholderia) cepacia causing CF centre epidemics in North America and Britain. Nature Med 1995; 1: 661-666.

28. Goldstein R, Sun L, Jiang R-Z, Sajjan US, Forstner JF, Campanelli C. Structurally variant classes of pilus appendage fibers coexpressed from Burkholderia (Pseudomonas) cepacia. J Bacteriol 1995; 177: 1039-1052.

29. Sajjan US, Corey M, Karmali MA, Forstner JF. Binding of Pseudomonas cepacia to normal human intestinal mucin and respiratory mucin from patients with cystic fibrosis. $J$ Clin Invest 1991; 89: 648-656.

30. Sajjan US, Sylvester FA, Forstner J. Cable-piliated Burkholderia cepacia bind to cytokeratin 13 of epithelial cells. Infect Immun 1999; 68: 1787-1795.

31. Snouwaert JN, Brigman KK, Latour AM et al. An animal model for cystic fibrosis made by gene targeting. Science 1992; 257: $1083-1088$

32. Kent G, Oliver M, Foskett JK et al. Phenotypic abnormalities in long-term surviving cystic fibrosis mice. Pediatr Res 1996; 40: $233-241$.

33. Ramjeesingh M, Huan L-J, Wilschanski M et al. Assessment of the efficacy of in vivo CFTR protein replacement therapy in CF mice. Hum Gene Therapy 1998; 9: 521-528.

34. Henry DA, Campbell ME, LiPuma JJ, Speert DP. Identification of Burkholderia cepacia isolates from patients with cystic fibrosis and use of a simple new selective medium. $J$ Clin Microbiol 1997; 35: 614-619.

35. Falk P, Roth KA, Boren T, Westblom TU, Gordon JI, Normark $\mathrm{S}$. An in vitro adherence assay reveals that Helicobacter pylori exhibits cell lineage-specific tropism in the human gastric epithelium. Proc Natl Acad Sci USA 1993; 90: 2035-2039.

36. Mukai K, Yoshimura S, Anzai M. Effects of decalcification on immunoperoxidase staining. Am J Surg Pathol 1986; 10: 413419.

37. Parsons D, Harkema J, Grubb B, Boucher R. Inflammation and infection is extended in the nasal airways of mice following epithelial damage. Pediatr Pulmonol 1996; Suppl 13: Abstract no. 156

38. Joshi AK, Baichwal V, Ames GF. Rapid polymerase chain reaction amplification using intact bacterial cells. BioTechniques 1991; 10: 42,44-45.

39. Mahenthiralingam E, Simpson DA, Speert DP. Identification and characterization of a novel DNA marker associated with epidemic Burkholderia cepacia strains recovered from patients 
with cystic fibrosis. J Clin Microbiol 1997; 35: 808-816.

40. Franke WW, Schiller DL, Moll R et al. Diversity of cytokeratins. Differentiation specific expression of cytokeratin polypeptides in epithelial cells and tissues. J Mol Biol 1981; 153: $933-959$.

41. Gude W, Cosgrove G, Hirsch G. Respiratory system. In: Histological atlas of the laboratory mouse. New York, Plenum Press. 1982: 11-12.

42. Baltimore RS, Christie CDC, Smith GJW. Immunohistopathologic localization of Pseudomonas aeruginosa in lungs from patients with cystic fibrosis. Am Rev Respir Dis 1989; 140: $1650-1661$.

43. Morgan PR, Shirlaw PJ, Johnson NW, Leigh IM, Lane EB.
Potential applications of anti-keratin antibodies in oral diagnosis. J Oral Pathol 1987; 16: 212-222.

44. Moll R, Franke WW, Schiller DL, Geiger B, Krepler R. The catalog of human cytokeratins: patterns of expression in normal epithelia, tumors and cultured cells. Cell 1982; 31: $11-24$.

45. Sylvester FA, Sajjan US, Forstner JF. Burkholderia (basonym Pseudomonas) cepacia binding to lipid receptors. Infect Immun 1996; 64: 1420-1425.

46. Roger P, Puchelle E, Bajolet-Laudinat $\mathrm{O}$ et al. Fibronectin and $\alpha 5 \beta 1$ integrin mediate binding of Pseudomonas aeruginosa to repairing airway epithelium. Eur Respir J 1999; 13: 13011309. 